ISSN 0258-7122

Bangladesh J. Agril. Res. 38(4): 553-562, December 2013

\title{
EVALUATION OF MAINTAINER AND RESTORER LINES FOR YIELD AND YIELD CONTRIBUTING TRAITS OF RICE (Oryza sativa L.)
}

\author{
M. J. HASAN ${ }^{1}$, UMMA KULSUM ${ }^{2}$, L. F. LIPI ${ }^{2}$ \\ A. AKTER ${ }^{2}$ AND A. K. M. SHAMSUDDIN ${ }^{3}$
}

\begin{abstract}
An experiment was conducted at Bangladesh Rice Research Institute (BRRI), Gazipur during T.Aman season of 2007 with a view to evaluating seven maintainer and 30 restorer lines for yield and yield contributing characters for selecting promising maintainer and restorer lines for developing rice hybrids in our local environment. Significant variations were noticed among the parental lines for all the characters studied. The CMS lines Gan46A and BRRI9A could be used as female parents in hybrid seed production due to good yield and yield contributing characters recorded in their corresponding maintainer lines. Restorer line BR168R could offer high yield potentiality in heterosis breeding due to its superior yield contributing characters in local environment.
\end{abstract}

Keywords: Yield contributing characters, maintainer and restorer lines, hybrid rice.

\section{Introduction}

Yields of improved rice varieties in favourable conditions have reached to a plateau or even subsequently declined in many countries including Bangladesh. It is recommended that a large number of high performance varieties are required to accomplish specific socio-economic and agricultural needs. Bangladesh is the fourth largest producer and consumer of rice in the world with an annual production ranging from 21 to 22 million tons. About $75 \%$ of the total cropped area is covered by rice and more than $60 \%$ of the labor force is engaged in rice production. Rice alone contributes around $10 \%$ to the GDP. Thus the single crop rice has a multiple effect on our daily life and economy (Iftekharuddaula et al., 2011).

It provides $75 \%$ of the calories and $55 \%$ of the proteins in the average daily diet of the people (Bhuiyan et al., 2002). To meet the challenge of producing more rice under those constraints, we need new technologies like hybrid rice because it gives $15-30 \%$ yield advantage over inbred rice. Moreover, hybrid rice has also shown better performance under adverse conditions like drought and saline conditions. Increasing demand for rice, especially in developing countries hybrid rice is considered as a viable alternative technology for breaking the

\footnotetext{
${ }^{1}$ Principal Scientific Officer, ${ }^{2}$ Scientific Officer, Hybrid Rice, Plant Breeding Division, Bangladesh Rice Research Institute (BRRI), Gazipur, ${ }^{3}$ Professor, Department of Genetics \& Plant Breeding, Bangladesh Agricultural University (BAU), Mymensingh, Bangladesh. The article is a part of Ph. D work of the main author.
} 
present yield ceiling of modern varieties. So far, One hundred and eight (108) hybrid rice varieties have been released from National Seed Board under various private companies and public organization (SCA, 2012).

Majority of these hybrids are imported from China. In boro seasons of 20112012, total sold hybrid rice seed was 8800 MT of which 45\% were imported from China and the rest 55\% from local production (Huda and Ali, 2012). Local production of hybrid rice seed can save lots of foreign currency and make a remarkable impact on our national economy. The knowledge of yield contributing traits is very much important for effective initiation of any hybrid research programme. Evaluation of parental lines for yield contributing traits could lead heterotic hybrid combination development in our local conditions. So, the knowledge of yield contributing traits of parental lines is very much important. There is ample scope to study the yield contributing traits of parental lines of hybrid rice under local environment. With this view, this study was undertaken to evaluate the maintainer and restorer lines for yield contributing traits of hybrid rice.

\section{Materials and Method}

The experiment was conducted at the experimental field of Bangladesh Rice Research Institute (BRRI), Gazipur during T. Aman season 2007. Seven maintainer and 30 restorer lines were evaluated to identify promising parental lines in respect of yield contributing traits for developing heterotic rice hybrids. Twenty one days old single seedling was transplanted with a spacing of $20 \times$ $15 \mathrm{~cm}$ in RCB design with three replications. The unit plot size was $1.8 \mathrm{~m} \times$ $1.0 \mathrm{~m}$. Adequate soil fertility was ensured by applying Urea-TSP-MP-Gypsum$\mathrm{ZnSO}_{4} @$ 150:100:70:60:10 kg/ha, respectively. Total TSP, MP, gypsum, and $\mathrm{ZnSO}_{4}$ were applied during final land preparation. The urea was applied in three installments, at 15 days after transplanting (DAT), 30 DAT, and 45 DAT. Necessary intercultural operations was carried out during cropping period for proper growth and development of the plants. Five sample plants were randomly selected from each plot excluding the border plants and the following data were recorded: number of effective tillers/ plant, days to $50 \%$ flowering (d), days to maturity (d), flag leaf length $(\mathrm{cm})$, number of panicles $/ \mathrm{m}^{2}$, panicle weight $(\mathrm{g})$, spikelet fertility (\%), 1000-grain weight (g) and grain yield/plot (kg). Data were analyzed according to MSTAT C software.

\section{Results and Discussion}

Analysis of variance showed the presence of significant variation among the maintainer lines in respect of their yield and yield contributing characters (Table 1). The knowledge of yield contributing characters is of prime importance for the selection of promising parental lines for development of hybrid variety in rice. The maximum number of effective tillers was recorded in Gan46B (6.3), which were significantly superior to all other maintainer lines. Number of effective 
tillers/plant in II32B, D.ShanB, and BRRI9B were low and statistically similar. Wazuddin and Julfiquar (2002) reported highly significant variation for number of effective tillers/plant among B lines in rice. Tahir et al. (2002) reported very early and very late flowering among some genotypes of rice. Days to maturity in the maintainer lines ranged from 94 to 119 days and D.ShanB (94 days) was the earliest. This was followed by Jin23B, IR78362B, and II32B. Short duration lines may be a good source for breeder to use as parents. BRRI9B had only 111 days to reach maturity (Table 2 and 3). So, its counterpart CMS line BRRI9A has open up an opportunity to breed short duration hybrid for T.Aman season.

Table 1. Analysis of variance for yield and yield contributing characters of maintainer lines.

\begin{tabular}{l|l|l|c|r}
\hline \multicolumn{1}{c|}{ Characters } & $\begin{array}{c}\text { Replication } \\
(\mathrm{n}-1)=2\end{array}$ & $\begin{array}{c}\text { Genotype } \\
(\mathrm{n}-1)=6\end{array}$ & $\begin{array}{c}\text { Error } \\
(\mathrm{n}-1)(\mathrm{n}-1)=12\end{array}$ & CV (\%) \\
\hline No. of effective tillers/plant & 0.207 & $2.226^{* *}$ & 0.111 & 6.94 \\
Days to 50\% flowering (d) & 7.429 & $199.714^{* *}$ & 3.929 & 2.52 \\
Days to maturity (d) & 50.143 & $178.000^{* *}$ & 9.143 & 2.83 \\
Flag leaf length (cm) & 28.304 & $253.947^{* *}$ & 3.641 & 5.59 \\
No. of panicles/m & 53.309 & $4275.108^{* *}$ & 26.005 & 3.45 \\
Panicle wt (g) & 0.043 & $3.483^{* *}$ & 0.060 & 7.86 \\
Spikelet fertility (\%) & 1.552 & $214.962^{* *}$ & 45.038 & 9.31 \\
1000-grain wt (g) & 0.336 & $41.637^{* *}$ & 0.786 & 3.77 \\
Grain yield/plot (g) & 793.390 & $62665.850^{* *}$ & 1285.211 & 7.74 \\
\hline
\end{tabular}

** Significant at $1 \%$ level of probability

Flag leaf plays very important role in photosynthesis and it helps in accumulating dry matter that ultimately translocates into grain. According to (Wan and Shong, 1981) flag leaf plays an important role in grain yield of rice. Gan46B possessed the highest flag leaf length $(50 \mathrm{~cm})$, while the lowest in Jin23B $(26.70 \mathrm{~cm})$. Number of panicles $/ \mathrm{m}^{2}$ ranged from 86.65 to 193.2 with the mean value of 147.82 (Table 2). Maximum number of panicles $/ \mathrm{m}^{2}$ was recorded in Jin23B (193.2) followed by that in IR78362B (189.60) and IR58025B (156.2). The maintainer line II32B gave the lowest number of panicles $/ \mathrm{m}^{2}$ (Table 3 ).

Maximum number of panicles $/ \mathrm{m}^{2}$ was recorded in Jin23B (193.2) followed by that of IR78362B (189.60) and IR58025B (156.2). The maintainer line II32B gave the lowest number of panicles $/ \mathrm{m}^{2}$ (Table 3). Panicle weight varied significantly among the maintainer lines and it ranged from 1.82 to $4.74 \mathrm{~g}$ with a mean value of $3.13 \mathrm{~g}$. Gan46B gave the highest $(4.74 \mathrm{~g})$ followed by BRRI9B (4.17 g) and II32B (3.69 g) and the lowest in Jin23B (1.82 g). BRRI9B is a newly developed maintainer line with gambiaca cyto-source and found to be very promising for panicle weight that ultimately leads to grain yield. Spikelet fertility varied significantly among the maintainer lines. 
Table 2. Mean with standard error and range for yield and yield contributing characters of maintainer lines.

\begin{tabular}{l|c|c}
\hline \multicolumn{1}{c|}{ Characters } & Mean \pm SE & Range \\
\hline No. of effective tillers/plant & $4.81 \pm 0.19$ & $4.00-6.30$ \\
Days to 50\% flowering (d) & $78.71 \pm 1.73$ & $66.00-90.00$ \\
Days to maturity (d) & $107.00 \pm 1.74$ & $94.00-119.00$ \\
Flag leaf length (cm) & $34.13 \pm 1.97$ & $26.70-50.00$ \\
No. of panicles/m ${ }^{2}$ & $147.82 \pm 7.88$ & $86.65-193.2$ \\
Panicle wt (g) & $3.13 \pm 0.23$ & $1.82-4.74$ \\
Spikelet fertility (\%) & $72.06 \pm 2.09$ & $61.86-82.48$ \\
1000-grain wt (g) & $23.48 \pm 0.79$ & $19.40-28.87$ \\
Grain yield/plot (g) & $463.11 \pm 30.59$ & $345.50-769.70$ \\
\hline
\end{tabular}

Spikelet fertility ranged from 61.86 to $82.48 \%$ with a mean value of $72.06 \%$. The highest spikelet fertility was recorded in BRRI9B (82.48\%) followed by Gan46B (81\%) and the lowest in IR78362B (61.86\%) (Table 3). High spikelet fertility enhances yield potentiality of a variety. This result suggested that BRRI9B could offer high yield potentiality in hybrid rice.

Table 3. Mean values for yield and yield contributing characters of maintainer lines.

\begin{tabular}{l|c|c|c|c|c|c|c}
\hline \multicolumn{1}{c}{ Characters } & IR58025B & II32B & Jin23B & IR78362B & D.ShanB & Gan46B & BRRI9B \\
\hline $\begin{array}{l}\text { No. of effective } \\
\text { tillers/plant }\end{array}$ & $4.777 \mathrm{c}$ & $4.000 \mathrm{~d}$ & $5.067 \mathrm{bc}$ & $5.400 \mathrm{~b}$ & $4.000 \mathrm{~d}$ & $6.300 \mathrm{a}$ & $4.100 \mathrm{~d}$ \\
$\begin{array}{l}\text { Days to 50\% } \\
\text { flowering (d) }\end{array}$ & $83.00 \mathrm{c}$ & $77.00 \mathrm{~d}$ & $74.00 \mathrm{e}$ & $75.00 \mathrm{de}$ & $66.00 \mathrm{f}$ & $90.00 \mathrm{a}$ & $86.00 \mathrm{~b}$ \\
$\begin{array}{l}\text { Days to } \\
\text { maturity (d) }\end{array}$ & $110.0 \mathrm{bc}$ & $107.0 \mathrm{~cd}$ & $104.0 \mathrm{~d}$ & $104.0 \mathrm{~d}$ & $94.00 \mathrm{e}$ & $119.0 \mathrm{a}$ & $111.0 \mathrm{~b}$ \\
$\begin{array}{l}\text { Flag leaf } \\
\text { length (cm) }\end{array}$ & $32.50 \mathrm{c}$ & $44.10 \mathrm{~b}$ & $26.70 \mathrm{~d}$ & $27.40 \mathrm{~d}$ & $27.90 \mathrm{~d}$ & $50.00 \mathrm{a}$ & $30.30 \mathrm{c}$ \\
$\begin{array}{l}\text { No. of panicles/m }{ }^{2} \\
\text { Panicle }\end{array}$ & $156.2 \mathrm{~b}$ & $86.65 \mathrm{e}$ & $193.2 \mathrm{a}$ & $189.6 \mathrm{a}$ & $145.2 \mathrm{c}$ & $146.3 \mathrm{c}$ & $117.5 \mathrm{~d}$ \\
$\begin{array}{l}\text { weight (g) } \\
\begin{array}{l}\text { Spikelet } \\
\text { fertility (\%) }\end{array}\end{array}$ & $2.473 \mathrm{~d}$ & $3.690 \mathrm{c}$ & $1.817 \mathrm{e}$ & $2.430 \mathrm{~d}$ & $2.560 \mathrm{~d}$ & $4.740 \mathrm{a}$ & $4.173 \mathrm{~b}$ \\
$\begin{array}{l}1000-\text { grain wt (g) } \\
\text { Grain }\end{array}$ & $19.40 \mathrm{~d}$ & $25.48 \mathrm{bc}$ & $20.00 \mathrm{~d}$ & $19.83 \mathrm{~d}$ & $26.01 \mathrm{~b}$ & $24.80 \mathrm{c}$ & $28.87 \mathrm{a}$ \\
yield/plot (g) & $384.1 \mathrm{~cd}$ & $387.1 \mathrm{~cd}$ & $475.7 \mathrm{~b}$ & $393.8 \mathrm{c}$ & $345.5 \mathrm{~d}$ & $769.7 \mathrm{a}$ & $485.9 \mathrm{~b}$ \\
\hline
\end{tabular}

Values with common letter(s) are statistically identical at $5 \%$ level of probability

The highest 1000-grain weight was recorded in BRRI9B (28.87g) followed by D.ShanB (26.01 g) and the lowest in IR58025B (19.40 g) with a mean value 
of $23.48 \mathrm{~g}$ (Table 2 and 3). Mondal et al. (2005) also found such variation for 1000 grain weight in some modern transplant aman rice. Grain yield/plot had highly significant variation among the maintainer lines. It ranged from 345.5 to $769.7 \mathrm{~g}$ with a mean value of $463.11 \mathrm{~g}$. Highest plot yield was recorded in Gan46B (769.7 g) followed by that in BRRI9B (485.9 g) and the lowest in D.ShanB (345.5 g). Evaluation of the maintainer lines for their yield performance showed that the line Gan46B was the best line for number of effective tillers, flag leaf length, spikelet fertility, and also for yield/plot. But the line was late in flowering and maturity. Similarly BRRI9B, a maintainer line developed by BRRI, proved its yield potentiality through spikelet fertility, 1000-grain weight, and grain yield/plot having medium duration for maturity.

Analysis of variance showed the presence of significant variation among the restorer lines in respect of yield and yield contributing characters (Table 4). The knowledge of yield contributing traits of hybrid rice is of prime importance for the selection of promising parental lines for commercially viable $F_{1}$ hybrid seed production. Number of effective tillers/hill exhibited significant variation among the restorer lines. Maximum number of tillers was recorded in BR7013-62-1-1R (8.7) followed by that in BR168R and BR736R. It is clearly evident that BRRI developed restorer lines showed superiority over IRRI and Chinese bred restorer lines in respect of effective tiller number. The probable reason of difference in producing effective tillers/hill is the genetic make up of the variety, which is primarily influenced by heredity. Ramesha et al. (1999) reported that percentage of effective tillers/hill were higher in low tillering cultivars of rice than in high.

Table 4. Analysis of variance for yield and yield contributing characters of restorer lines.

\begin{tabular}{l|l|l|l|l}
\hline \multicolumn{1}{c|}{ Characters } & \multicolumn{1}{c}{$\begin{array}{c}\text { Replication } \\
(\mathrm{n}-1)=2\end{array}$} & $\begin{array}{c}\text { Genotype } \\
(\mathrm{n}-1)=29\end{array}$ & $\begin{array}{c}\text { Error } \\
(\mathrm{n}-1)(\mathrm{n}-1)=58\end{array}$ & CV (\%) \\
\hline No. of effective tillers/plant & 0.25 & $2.83 * *$ & 0.18 & 6.02 \\
Days to 50\% flowering (d) & 0.23 & $195.45^{* *}$ & 5.85 & 2.64 \\
Days to maturity (d) & 8.63 & $249.59 * *$ & 10.91 & 2.78 \\
Flag leaf length (cm) & 24.38 & $54.08 * *$ & 17.22 & 11.37 \\
Number of panicles/m ${ }^{2}$ & 41.74 & $1564.53 * *$ & 120.57 & 6.34 \\
Panicle wt (g) & 0.06 & $1.46 * *$ & 0.01 & 4.00 \\
Spikelet fertility (\%) & 8.12 & $73.33 * *$ & 12.23 & 4.32 \\
1000-grain weight (g) & 0.41 & $34.14 * *$ & 0.49 & 2.92 \\
Grain yield/plot (g) & 4030.56 & $149393.30 * *$ & 1087.88 & 4.29 \\
\hline
\end{tabular}

** Significant at $1 \%$ level of probability

Number of days required for $50 \%$ flowering ranged from 73 to 105 days with a mean value of 91.57 days (Table 5). The restorer line IR69716-37-1-1-5-IR was 
found earliest to 50\% flowering (73 days), while the restorer line IR69702-3-23R showed late to 50\% flowering. Tahir et al. (2002) reported significant variation for days to 50\% flowering in rice. Chakraborty and Hajarika (1994) also reported similar results in rice.

Table 5. Mean with standard error and range for yield contributing characters of restorer lines

\begin{tabular}{lcc}
\hline \multicolumn{1}{c}{ Characters } & Mean \pm SE & Range \\
\hline No. of effective tillers/plant & $6.97 \pm 0.11$ & $5.00-8.70$ \\
Days to 50\% flowering (d) & $91.57 \pm 0.87$ & $73.00-105.00$ \\
Days to maturity (d) & $118.90 \pm 0.99$ & $98.00-135.00$ \\
Flag leaf length (cm) & $36.49 \pm 0.57$ & $28.70-45.70$ \\
Number of panicles $/ \mathrm{m}^{2}$ & $173.28 \pm 2.56$ & $125.00-215.00$ \\
Panicle weight (g) & $2.47 \pm 0.07$ & $1.30-4.20$ \\
Spikelet fertility (\%) & $80.99 \pm 0.60$ & $69.74-89.03$ \\
1000-grain weight (g) & $24.02 \pm 0.36$ & $19.09-30.59$ \\
Grain yield/plot (g) & $768.74 \pm 23.45$ & $374.10-1182.00$ \\
\hline
\end{tabular}

Days to maturity in the restorer lines ranged from 98 to 135 days and IR697023-2-3R took highest (135 days) to maturity, while IR69716-37-1-1-5-IR took the lowest (98 days) and it was the earliest. BR827R, BR168R, and BR736R were statistically same for days to maturity (Table 6). Karim et al. (2007) found highly significant mean sum of square due to genotypes for days to maturity in rice.

Flag leaf length varied significantly among the restorer lines and ranged from 28.7 to $45.7 \mathrm{~cm}$ with a mean value of $36.49 \mathrm{~cm}$. The maximum flag leaf length was recorded in IR69701-41-3-IR $(45.7 \mathrm{~cm})$ and the shortest in IR64R $(28.7 \mathrm{~cm})$ (Table 6). Flag leaf plays very important and significant role in grain filling of rice. The grain yield and yield related traits were positively related to flag leaf area. Flag leaf plays an important role in grain yield of rice (Sheela et al., 1990; Raj and Tripathi, 2000). Number of panicles $/ \mathrm{m}^{2}$ is very important trait to measure yield contributing characters in rice. Analysis of variance indicated significant variation among the restorer lines. It ranged from 125 to 215 with mean value of 173.28. Maximum number of panicles $/ \mathrm{m}^{2}$ was recorded in BR168R (215) followed by that in BR7013-62-1-1R and BR736R (Table 6). BRRI developed restorer lines showed superiority over IRRI; Indian and Chinese bred restorer lines in terms of number of panicles $/ \mathrm{m}^{2}$. Variation in panicle weight was found significant among the restorer lines. The maximum panicle weight was recorded in BR827R (4.20 g) followed by that in IR68011-15-1-12-3R and BR168R and lowest in IR64R $(1.30 \mathrm{~g})$. Spikelet fertility differed significantly among the restorer lines. It ranged from 69.74 to $89.03 \%$ with a mean value of $80.99 \%$ (Table 5). 
Table 6. Mean values for yield and yield contributing characters of restorer lines.

\begin{tabular}{|c|c|c|c|c|c|c|c|c|c|}
\hline Genotypes & $\begin{array}{c}\text { No. of } \\
\text { effective } \\
\text { tillers/plant }\end{array}$ & $\begin{array}{c}\text { Days to } \\
50 \% \\
\text { flowering } \\
\text { (d) }\end{array}$ & $\begin{array}{l}\text { Days to } \\
\text { maturity } \\
\text { (d) }\end{array}$ & $\begin{array}{c}\text { Flag leaf } \\
\text { length }(\mathrm{cm})\end{array}$ & $\begin{array}{c}\text { No. of } \\
\text { panicles } / \mathrm{m}^{2}\end{array}$ & $\begin{array}{l}\text { Panicle wt } \\
\text { (g) }\end{array}$ & $\begin{array}{l}\text { Spikelet } \\
\text { fertility } \\
(\%)\end{array}$ & $\begin{array}{c}\text { 1000-grain } \\
\text { wt (g) }\end{array}$ & $\begin{array}{c}\text { Grain } \\
\text { yield/plot } \\
\text { (g) }\end{array}$ \\
\hline BR827R & $7.40 \mathrm{~d}$ & 100.0 bc & $130.0 \mathrm{c}$ & 35.50 hij & $185.0 \mathrm{~d}$ & $4.20 \mathrm{a}$ & 85.60 cde & 20.44 o & $840.9 \mathrm{~g}$ \\
\hline BR168R & $8.60 \mathrm{ab}$ & 100.0 bc & 129.0 c & 37.30 ghi & $215.0 \mathrm{a}$ & $3.53 \mathrm{~cd}$ & $87.75 \mathrm{ab}$ & 20.47 o & 1166.0 a \\
\hline BR736R & $8.40 \mathrm{~b}$ & $101.0 \mathrm{~b}$ & 130.0 c & 40.40 cde & $208.0 \mathrm{~b}$ & $3.50 \mathrm{~d}$ & $83.30 \mathrm{fg}$ & 20.33 o & $1044.0 \mathrm{c}$ \\
\hline BR6839-41-5-1R & $7.40 \mathrm{~d}$ & $89.00 \mathrm{~h}$ & $118.0 \mathrm{fg}$ & 39.80 ef & 181.0 de & $3.58 \mathrm{c}$ & 84.11 ef & 27.99 c & $960.7 \mathrm{e}$ \\
\hline BR7013-62-1-1R & $8.70 \mathrm{a}$ & $90.00 \mathrm{~h}$ & $118.0 \mathrm{fg}$ & $43.30 \mathrm{~b}$ & $211.0 \mathrm{ab}$ & $2.30 \mathrm{k}$ & 79.65 jkl & $17.16 \mathrm{q}$ & 673.01 \\
\hline BR7011-37-1-2R & $5.90 \mathrm{i}$ & $90.00 \mathrm{~h}$ & $119.0 \mathrm{f}$ & $31.00 \mathrm{~m}$ & $148.0 \mathrm{kl}$ & $2.65 \mathrm{~h}$ & 85.31 de & $30.08 \mathrm{~b}$ & $620.8 \mathrm{n}$ \\
\hline M.H.63R & $8.00 \mathrm{c}$ & 82.00 jk & 109.0 jk & $35.20 \mathrm{ij}$ & 199.0 c & $2.71 \mathrm{~g}$ & 80.91 hijk & $27.36 \mathrm{~d}$ & $993.8 \mathrm{~d}$ \\
\hline IR40750R & $7.067 \mathrm{e}$ & $94.00 \mathrm{f}$ & 122.0 e & $32.20 \mathrm{klm}$ & 178.0 ef & 2.05 op & 85.68 cde & $19.09 \mathrm{p}$ & $735.3 \mathrm{j}$ \\
\hline IR7320-44-2-3-IR & $6.40 \mathrm{gh}$ & $95.00 \mathrm{ef}$ & $121.0 \mathrm{e}$ & $39.80 \mathrm{ef}$ & $160.0 \mathrm{ij}$ & $2.16 \mathrm{~m}$ & $77.30 \mathrm{~m}$ & $24.13 \mathrm{~h}$ & $551.0 \mathrm{p}$ \\
\hline PSBRC 82R & $6.00 \mathrm{i}$ & $89.00 \mathrm{~h}$ & $114.0 \mathrm{~h}$ & $33.50 \mathrm{jkl}$ & $150.0 \mathrm{k}$ & $2.26 \mathrm{kl}$ & $79.46 \mathrm{kl}$ & $24.99 \mathrm{~g}$ & $696.7 \mathrm{k}$ \\
\hline IR68011-15-1-12-3R & $7.10 \mathrm{e}$ & $94.00 \mathrm{f}$ & $121.0 \mathrm{e}$ & $33.70 \mathrm{jkl}$ & 178.0 ef & $3.75 \mathrm{~b}$ & 83.95 ef & $26.32 \mathrm{e}$ & $1131.0 \mathrm{~b}$ \\
\hline IR73004-107-3-3-2R & $6.60 \mathrm{fg}$ & $98.00 \mathrm{~d}$ & $127.0 \mathrm{~d}$ & $42.60 \mathrm{bc}$ & $165.0 \mathrm{hi}$ & 2.10 no & $79.39 \mathrm{kl}$ & $22.81 \mathrm{k}$ & $770.1 \mathrm{i}$ \\
\hline IR73004-7-3-3-3R & $7.00 \mathrm{e}$ & 95.00 ef & $122.0 \mathrm{e}$ & $35.00 \mathrm{ij}$ & 175.0 ef & $2.73 \mathrm{~g}$ & 81.25 hijk & $23.71 \mathrm{i}$ & 633.5 n \\
\hline IR64R & $6.60 \mathrm{fg}$ & $86.00 \mathrm{i}$ & $111.0 \mathrm{i}$ & $28.70 \mathrm{n}$ & $165.0 \mathrm{hi}$ & $1.30 \mathrm{u}$ & 80.81 hijk & $23.30 \mathrm{j}$ & $695.2 \mathrm{k}$ \\
\hline
\end{tabular}


Table 6. Cont'd.

\begin{tabular}{l|c|c|c|c|c|c|c|c|c}
\hline \multicolumn{1}{c}{ Genotypes } & $\begin{array}{c}\text { No. of } \\
\text { effective } \\
\text { tillers/plant }\end{array}$ & $\begin{array}{c}\text { Days to } \\
\begin{array}{c}50 \% \\
\text { flowering } \\
(\mathrm{d})\end{array}\end{array}$ & $\begin{array}{c}\text { Days to } \\
\text { maturity } \\
\text { (d) }\end{array}$ & $\begin{array}{c}\text { Flag leaf } \\
\text { length }(\mathrm{cm})\end{array}$ & $\begin{array}{c}\text { No. of } \\
\text { panicles/m² }\end{array}$ & $\begin{array}{c}\text { Panicle wt } \\
\text { (g) }\end{array}$ & $\begin{array}{c}\text { Spikelet } \\
\text { fertility } \\
\text { (\%) }\end{array}$ & $\begin{array}{c}\text { 1000-grain } \\
\text { wt (g) }\end{array}$ & $\begin{array}{c}\text { Grain } \\
\text { yield/plot } \\
\text { (g) }\end{array}$ \\
\hline IR46R & $5.60 \mathrm{j}$ & $96.00 \mathrm{e}$ & $122.0 \mathrm{e}$ & $34.30 \mathrm{jk}$ & $143.3 \mathrm{~lm}$ & $2.12 \mathrm{mn}$ & $73.30 \mathrm{no}$ & $30.59 \mathrm{a}$ & $476.4 \mathrm{q}$ \\
IR71137-328-2-3-3-3-2R & $6.30 \mathrm{~h}$ & $85.00 \mathrm{i}$ & $111.0 \mathrm{i}$ & $40.60 \mathrm{cde}$ & $158.0 \mathrm{j}$ & $3.07 \mathrm{e}$ & $71.50 \mathrm{op}$ & $30.10 \mathrm{~b}$ & $619.1 \mathrm{n}$ \\
IR73885-1-4-1-4-4-3-6R & $7.10 \mathrm{e}$ & $92.00 \mathrm{~g}$ & $117.0 \mathrm{~g}$ & $30.40 \mathrm{mn}$ & $178.0 \mathrm{ef}$ & $1.71 \mathrm{r}$ & $69.74 \mathrm{p}$ & $21.33 \mathrm{n}$ & $454.3 \mathrm{r}$ \\
IR69716-37-1-1-5-IR & $5.00 \mathrm{k}$ & $73.00 \mathrm{~m}$ & $98.00 \mathrm{~m}$ & $37.70 \mathrm{fgh}$ & $125.0 \mathrm{o}$ & $2.45 \mathrm{ij}$ & $74.71 \mathrm{n}$ & $25.98 \mathrm{e}$ & $422.4 \mathrm{~s}$ \\
AjayaR & $8.00 \mathrm{c}$ & $95.00 \mathrm{ef}$ & $121.0 \mathrm{e}$ & $39.70 \mathrm{ef}$ & $197.0 \mathrm{c}$ & $1.41 \mathrm{t}$ & $78.67 \mathrm{~lm}$ & $20.28 \mathrm{o}$ & $802.7 \mathrm{~h}$ \\
IR73013-95-1-3-2R & $6.97 \mathrm{e}$ & $95.00 \mathrm{ef}$ & $122.0 \mathrm{e}$ & $38.80 \mathrm{efg}$ & $176.0 \mathrm{ef}$ & $2.81 \mathrm{f}$ & $84.21 \mathrm{ef}$ & $23.65 \mathrm{ij}$ & $847.8 \mathrm{~g}$ \\
IR44675R & $7.00 \mathrm{e}$ & $83.00 \mathrm{j}$ & $107.0 \mathrm{l}$ & $34.80 \mathrm{j}$ & $172.0 \mathrm{fg}$ & $2.03 \mathrm{p}$ & $80.22 \mathrm{ijkl}$ & $24.39 \mathrm{~h}$ & $637.3 \mathrm{n}$ \\
IR32809-26-3-3R & $5.50 \mathrm{j}$ & $99.00 \mathrm{~cd}$ & $129.0 \mathrm{c}$ & $35.10 \mathrm{ij}$ & $138.0 \mathrm{~m}$ & $2.64 \mathrm{~h}$ & $81.59 \mathrm{ghij}$ & $27.19 \mathrm{~d}$ & $587.6 \mathrm{o}$ \\
IR72887-38-1-3-2R & $7.80 \mathrm{c}$ & $104.0 \mathrm{a}$ & $133.0 \mathrm{~b}$ & $35.30 \mathrm{ij}$ & $195.0 \mathrm{c}$ & $2.42 \mathrm{j}$ & $81.81 \mathrm{ghi}$ & $21.74 \mathrm{~m}$ & $1048.0 \mathrm{c}$ \\
IR72906-24-1-3-IR & $7.40 \mathrm{~d}$ & $94.00 \mathrm{f}$ & $122.0 \mathrm{e}$ & $40.10 \mathrm{def}$ & $185.0 \mathrm{~d}$ & $1.82 \mathrm{q}$ & $89.02 \mathrm{a}$ & $27.28 \mathrm{~d}$ & $1182.0 \mathrm{a}$ \\
IR69702-3-2-3R & $6.70 \mathrm{f}$ & $105.0 \mathrm{a}$ & $135.0 \mathrm{a}$ & $42.40 \mathrm{bcd}$ & $168.0 \mathrm{gh}$ & $2.48 \mathrm{i}$ & $81.28 \mathrm{hijk}$ & $22.08 \mathrm{~lm}$ & $881.7 \mathrm{f}$ \\
IR69701-41-3-IR & $8.00 \mathrm{c}$ & $100.00 \mathrm{bc}$ & $127.0 \mathrm{~d}$ & $45.70 \mathrm{a}$ & $180.0 \mathrm{de}$ & $2.11 \mathrm{mn}$ & $87.49 \mathrm{abc}$ & $22.45 \mathrm{kl}$ & $999.6 \mathrm{~d}$ \\
\hline
\end{tabular}

Values with same letter(s) are statistically identical at $5 \%$ level of probability. 
The highest spikelet fertility was recorded in IR72906-24-1-3-IR (89.02\%) followed by that in BR168R (87.75\%) and the lowest in IR73885-1-4-1-4-4-3-6R (69.74\%). Thousand grain weight varied significantly among the tested restorer lines. The highest 1000-grain weight was recorded in IR46R (30.59 g) followed by that in IR71137-328-2-3-3-3-2R (30.10 g), BR7011-37-1-2R (30.08 g) and the lowest in IR40750R (19.09 g) with a mean value of $24.02 \mathrm{~g}$. Mondal et al. (2005) studied modern cultivars of transplanted aman rice and reported 1000-grain weight differed significantly among the cultivars. Grain yield/plot was found highly significant among the restorer lines. It ranged from 374.1 to $1182 \mathrm{~g}$ with a mean value of $768.74 \mathrm{~g}$. Highest plot yield was recorded in IR72906-24-1-3-IR (1182 g) followed by that in BR168R (1166 g) and the lowest in M.H.77R (374.1 g). The genotypes produced higher number of effective tillers/hill and higher number of grains/panicle showed high grain yield in rice (Kusutani et al., 2000; Dutta et al., 2002). Restorer line BR168R gave the second highest yield and exhibited superiority for number of effective tillers/hill, number of panicles $/ \mathrm{m}^{2}$, and spikelet fertility.

\section{Conclusions}

Due to good yield and yield contributing characters of Gan46B and BRRI9B, their corresponding A-lines could be used as female parents in hybrid seed production if early maturing restorer lines specific to these A lines are available. Restorer line BR168R could offer high yield potentiality in heterosis breeding due to its superior yield contributing characters in local environment and selection of such restorer line for hybrid seed production would be effective if growth duration of CMS parent was more or less similar to BR168R as well as proper row ratio of this combination, appropriate amount of $\mathrm{GA}_{3}$ doses with proper application time, management practices and supplementary pollination is maintained for hybrid rice seed production.

\section{References}

Bhuiyan, N. I., D. N. R. Paul and M. A. Jabbar. 2002. Feeding the extra millions by 2025: Challenges for rice research and extension in Bangladesh. A key note paper presented on national workshop. Pp.9.

Chakraborty S. and M. H. Hajarika. 1994. Estimation of various genetic parameters of yield and yield components of rice. Oryza 31: 226-227.

Dutta, R. K., M. A. Baset Mia and S. Khanam. 2002. Plant architecture and growth characteristics of fine grain and aromatic rice and their relation with grain yield. IRC Newslett. 51: 51-56.

Huda, N. and Shahjahan Ali. 2012. Hybrid rice seed technology in Bangladesh. Issues and Considerations. Seminar presented at BARC, Farmgate, Dhaka on September 18, 2012 
Ifterkharuddaula, K. M., M. R. Islam, T. L. Aditya, J. K. Biswas and M. K. Bashar. 2011. Development of climate change resilient rice varieties: Current status and potential. Souvenir, SAARC seed congress and fair 2011, held at Bangabandhu International Conference Centre during 10-12 April, 2011, Dhaka, Bangladesh.

Karim, D. U., M. N. Sarkar, A. Siddique, M. A. Khaleque Miah and M. Z. Hasnat. 2007. Variability and Genetic Parameter Analysis in Aromatic Rice. Int. J. Sustain. Crop Prod. 2(5) 15-18.

Kusutani, A., M. Tovata, K. Asanuma and J. Cui. 2000. Studies on the varietal differences of harvest index and morphological characteristics of rice. Japanese $J$. Crop Sci. 69: 359-364

Mondal, M. M. A., A. F. M. Islam and M. A. Siddique. 2005. Performance of 17 modern transplant aman cultivar in the northern region of Bangladesh. Bangladesh J. Crop Sci. 16: 23-29

Raj, A. and M. P. Tripathi. 2000. Varietal variations in flag leaf area and yield in deep water rice. Indian J. Plant Physiol. 5: 293-295.

Ramesha, M. A., B. C. Virakmath, M. Ahamad Ilyas and C. H. M. Vijaykumar. 1999. New CMS sources with stable mail sterility and better out crossing traits in rice. Indian J.Genet 59: 403-409.

Seed Certification Agency. 2012. List of released hybrid rice varieties from 1997 to 2011.

Sheela, G., V. N. Shai and Saran. 1990. Role of flag leaf on grain yield and spikelet sterility in rice cultivars. Oryza 27: 87-88.

Tahir, M. D., Wadan and A. Zada. 2002. Genetic variability of different plant yield characters in rice. Sarhad J. Agric. 18(2).

Wan, A. L. and Y. M. Shong. 1981. Studies on the relationship between flag leaf area and panicle weight in rice cultivars. Scienctia Agricultura Sinica 6: 21-28.

Wazuddin, M. and A. W. Julfiquar. 2002. Initiative towards development of parental materials for hybrid rice. Proceeding of the $1^{\text {st }}$ National Workshop on Research and Development of Hybrid Rice in Bangladesh held at BRRI, 5-6 January 2002. 